\title{
A Critical Analysis of the Nature and Effectiveness of a Floating Charge as a Security in Nigerian Law
}

\author{
Emuobo Emudainohwo \\ Faculty of Law, Delta State University, Oleh Campus, Oleh, Nigeria \\ Email: eemuobo@yahoo.co.uk
}

How to cite this paper: Emudainohwo, E. (2021). A Critical Analysis of the Nature and Effectiveness of a Floating Charge as a Security in Nigerian Law. Beijing Law Review, 12, 191-204.

https://doi.org/10.4236/blr.2021.121011

Received: December 16, 2020

Accepted: March 16, 2021

Published: March 19, 2021

Copyright $\odot 2021$ by author(s) and Scientific Research Publishing Inc. This work is licensed under the Creative Commons Attribution International License (CC BY 4.0).

http://creativecommons.org/licenses/by/4.0/

\begin{abstract}
The purpose of this research is to examine the character and efficacy of a floating charge as a security in Nigerian law. It argues that the disadvantages of a floating charge are so much making it a vulnerable security. The charge holder runs the risk of the company dissipating the assets attached to the charge which arguably is the most serious risk the charge holder faces. Furthermore, a floating charge usually will be deferred to any subsequent fixed legal charge created by the company over its assets. Similarly, if the company's debts are under a floating charge, a floating charge holder's asset will be made subject to or put under a lien or any set off created by the company with respect to the charged assets before crystallization. It uses the blackletter approach, relying particularly on the relevant provisions of the Nigerian Companies and Allied Matters Act and cases.
\end{abstract}

\section{Keywords}

Floating Charge, Company Security, Vulnerability, Fixed Charge, Nigeria

\section{Introduction}

The floating charge as a company security was recognized in English decisions of the 1870s, (Re Panama, New Zealand and Australian Royal Mail Co., 1870). It is a company security that is particular to the English Commonwealth although it had root in Roman law (Pennington, 1960). The capital requirement of a big company may not be met by its shareholders especially under the new dispensation which allows the company to carry on a variety of business as a going concern under the provision of the (Companies and Allied Matters Act, 2020, CAMA, section 35 (1). The company may then resort to borrowing to meet its 
capital requirement providing assurance by issuing debentures secured by a charge on the company's assets. At common law, a trading company has an implied power to borrow money for executing its objects (Bryan v Metropolitan Co, 1858) unless prohibited from doing so by its memorandum of association or by statute. Such trading company may also give security for loans and advances by creating a mortgage or charge over all or any of its property (Australian Auxiliary Steam Clip per Co. v. Mounsey, 1958) including its uncalled capital (Re Pyle Works, 1990). The power to borrow money and create debentures secured by a charge is now vested in companies by CAMA. Section 191 of CAMA gives a registered company the power to borrow money for its purposes and may mortgage or charge its assets and capital, to issue debentures, debenture stock and other security for any debt, liability or obligation of the company or of any third party. One of the major problems of the floating charge is its vulnerability. The vulnerability includes: the charge holder runs the risk of the company dissipating the assets attached to the charge which arguably is the most serious risk the charge holder faces. Furthermore, a floating charge usually will be deferred to any subsequent fixed legal charge created by the company over its assets. Similarly, if the company's debts are under a floating charge, a floating charge holder's asset will be made subject to or put under a lien or any set off created by the company with respect to the charged assets before crystallization. Also, a floating charge holder takes the company's assets subject to the interests of anyone claiming by title paramount. Also, there are some provisions in the Nigerian Companies and Allied Matters Act that further add to the vulnerability of a floating charge. These provisions relate to: preferential creditors (which affect the priority of the charge), defective floating charge (which affects the viability of the charge), cost of liquidation (which diminishes the available funds for the floating charge holders). The paper is divided into the following sections. Section 1 is introductory. Some relevant terms were defined in Section 2. Section 3 analyzed the theories and character of a floating charge. The legal importance of making a floating charge is highlighted in Section 4. Floating charge realization is the focus of Section 5. Section 6 examined the vulnerabilities of a floating charge. And Section 7 is the conclusion.

\section{Definition of Some Terms: Debenture and Fixed Charge}

\subsection{Debenture}

A debenture has been defined as: "an instrument issued by the company, normally but not necessarily, called on the face of it a debenture and providing for the payment of or acknowledging the indebtedness in a specified sum with interest thereon..." Palmer \& Schmitthoff (1976). A debenture has also been defined as a "security for a loan of money issued by a public company, usually creating a charge on whole or a part of the company's stock and property though not necessarily in the form of a mortgage" (Blacks, 1990). Also, section 868 (1) of 
CAMA defined a debenture as: a written acknowledgement of indebtedness by a company. In (Inter-Contractors Nigeria Ltd v. National Provident Fund Management Board, 1988) the Supreme Court described a debenture as follows: A debenture consists of a debt owed by a company secured by a deed which prescribes the conditions of the realization of the debt. A debenture may be created over the fixed or floating assets of the company

\section{Charge Securing Debenture}

Although a debenture is generally an acknowledgement of the company's indebtedness, it is unlikely that a creditor would accept naked debentures and more often than not, the company is obliged to charge its assets as security. A secured debenture is that which is secured either by fixed charge in specific or ascertainable company property or by a floating charge on the whole or particular assets of the company or both. (CAMA section 198 (1))

\subsection{Fixed Charge}

A charge is "an incumbrance, lien, claim, a burden or load, an obligation or duty, a liability" (Blacks, 1990). There is no statutory definition or detailed description of a fixed charge in Nigeria so that the common law concept of the fixed charge applies subject to some statutory modifications. At common law, a fixed charge is one attached to particular asset of a company at the time the charge is created (Illingsworth v Houldsworth, 1904). The fixed charge attaches to a specific property when it is created and the character the asset does not change during the subsistence of the charge (Pennington, 1995). It is not necessary that the property should exist at the time charge is made or that the company should be the owner; however, the property or the class of assets to which it belongs should be clearly explained in the document of the charge so that there can be no doubt whether the property is caught by the charge when it comes into existence or when the company acquires it (Tailby v Qfficial Receiver, 1888). When a charge is fixed, the asset is appropriated to the payment of the debt immediately or upon the debtor acquiring an interest in the future or after-acquired property. It follows from the foregoing description of a fixed charge that it may be created mainly over specific or ascertainable properties of the company present or future (e.g. land, buildings, trade machineries and other fixed assets of the company) apart from the shifting assets such as books, debts, stock in trade, raw materials and goods in process and this view is not without foundation ( $\operatorname{Re} G \mathrm{E}$ Turnbridge Ltd., 1994).

Section 198(2) of CAMA stipulates that "debentures may be secured either by a fixed charge (in certain of the company's property) or a floating charge (over all or some of the company's) assets..." appears to support that view. However, this traditional method of classifying a fixed or floating, charge may turn out to be of little significance in ascertaining the real nature of the charge in practical terms. Assets over which a fixed charge may be created are not necessarily those physically attached to premises and have been held to cover book debt (Siebe 
German \& Co. Ltd v Barclays Bank Ltd., 1979) as well as future and after acquired property (Holroyd $\mathrm{v}$ Marshal, 1862). Also the possibility of creating a fixed charge coupled with a licence to the chargor to deal with, or dispose of the charged assets in the business (Evans v Rival Quarries Ltd., 1910), informs the better view that the important factor (Smith, 2001) in determining whether a fixed charge can be created on shifting assets e.g. stock in trade, raw materials etc. is not the nature of assets as such but the fact that the debtor's freedom to manage the assets in the ordinary course of business is restricted (Siebe German \& Co. Ltd v Barclays Bank Ltd., 1979). Thus, the distinguishing feature of a fixed charge is in the restriction of the debtor company's freedom to manage its assets in the ordinary course of business as opposed to the nature of the assets as to being fixed or shifting (Re New Bullas Trading Ltd., 1994). A debenture secured by a fixed charge takes the form of a mortgage legal or equitable with the attendant rights and obligations of the parties as in the ordinary mortgage involving the individual (Knightsbridge Estates Trust Ltd v Byrne, 1940). A fixed charge is usually created in the same way as other mortgages, that is, the transfer of the company's proprietary interest in the fixed assets as security for a loan subject to cesser on redemption (Santley v. Wilde, 1899). A fixed charge expressed by way of a deed is a legal mortgage and the chargee has the rights of a legal mortgagee. (Smith, 2001). An equitable mortgage may also be created e.g. where the chargor deposits title deeds with the chargee so that the chargee has the rights of an equitable mortgagee (Ogundiani v Araba, 1978), but such rights may be postponed to those of a bonafide purchaser of the property mortgaged without notice (Animashnun v Olojo, 1990). In situation of series of debentures issued and protected by a fixed charge, it is necessary to have a trust deed appointing trustees and vesting the fixed charge in them.

The effect of creating this security is that the mortgage fastens at once on the property, and binds it in the hands of third parties who take from the company (Goode, 1988). The fixed charge prevents the chargor from disposing of the property subject to the charge without the approval of the chargee. Sections 203 and 204 of CAMA set out the events under which a fixed charge may be realized together with the remedies available to a fixed chargee. From the point of view of the chargee, the benefit of a fixed charge lies in the availability of a particular asset or group of assets to satisfy the creditor upon default by the debtor-company and in the priority of the charge over any floating charge created prior to or subsequent to the fixed charge, CAMA section 204) unless the earlier floating charge (Smith, 2001) contained a Negative Pledge Clause (NPC). The NPC is a drafting device, a clause introduced into the institution of the floating charge to ameliorate its vulnerability. The clause is in the form of a covenant binding the company not to, without the prior consent of the debenture holder, grant any subsequent security ranking in priority to or in pari pass with the existing charge. The fixed charge however has a major disadvantage for the chargee; because the assets subjects of security are already chosen and ascertained the chargee is confined to the particular assets charged in the event of enforcement of the 
security even where they are depreciating in value and/or insufficient to meet the company's debt, and is precluded from having recourse to other free assets of the company (Smith, 2001).

\section{Floating Charge: Theories and Character}

\subsection{Theories}

Pennington (1960) stated two theories on the character of a floating charge. The first is that the floating charge produces an interest over the whole assets of the debtor periodically subject to the debtor's power to sell the assets in normal business activities. The second is that the floating charge does not fasten to any specific asset but hovers over all assets until crystallisation. The latter is in agreement with the view of the court in (Illingsworth $v$ Houldsworth, 1904) where Lord Macnaghten stated that a floating charge hovers over the property which it is planned to impact or influence until an event occur which makes it attach to the subject matter of the charge. It will appear that the two theories are contradictory or conflicting. But generally, a floating charge can be described as an equitable interest in the properties or assets under the charge and it takes effect from the time or day of the security agreement (Goode, 2008), without preventing the company from dealing with the assets in normal business activities without prior authorisation of the charge (McCormack, 2009).

\subsection{Character}

A floating charge is characterized by three main features (Re Yorkshire Wool Combers Association Limited, 1903): 1) is a charge on categories of properties current and future 2) these categories of properties of the company can change occasionally and 3) it is understood that, till the charge fasten to the properties, the company may sell or manage the properties of the business. Section 203 (2) CAMA provides, and limits, the situations in which a floating charge can crystallize, and de-crystallize, in a manner that departs from what appears to be the settled view (Re Crompton \& Co. Ltd., 1914). There are a number of statutory characteristics of a floating charge that makes it elbow out the fixed charge. Unlike the fixed charge, the floating charge, pursuant to the clear provisions of section 203 (1) CAMA can be made over all properties or assets or undertakings, this as will be demonstrated shortly, makes the floating charge a better security for the financier. Not long ago, Stanley Bunton QC tried to bring some clarification to the subject of charges in (Re Cimex Tissues Limited, 1995). Amongst other things he pointed out, that "...the existence of some restrictions on the Company's dealing with the charged property is not inconsistent with a floating charge..." In (Re Yorkshire Woolcombers Association Limited 1903) Romer L.J stated that a floating charge envisages the liberty to carry on business with charged assets (Goode, 1988). It appears that the floating charge character of at common law is not different from the provision of section 203(1) CAM.A, to the effect that the floating charge, does not preclude the company from managing 
such assets (CAMA, section 180(2)). As parties can neither create a charge unknown to law (Re Cimex Tissues Limited, 1995) nor by mere labelling, a floating (or fixed) charge to be effective must have the essential characteristics (Armagh Shoes Limited, 1984). A priori, the stipulation of section 203(1) of CAMA must be followed. Taken literally, as it should be, it means that no restriction whatsoever can be permitted in a floating charge, save as allowed by statute. Although the common law generally permits different types of restrictions on the floating charge, the test is really one of degree rather than control itself. The only indication one can get on the type of restrictions, prohibitions or control one can place on a floating charge, usually is contained in sections 204 - 225 of CAMA which mention that future charges may be restricted by a floating charge. The legislative draftsmen in Nigeria therefore appear to have disregarded the various types of restrictions on a floating charge, adopting rather, only one type of restriction as stated by Hoffman J. in (Re Bright life Limited, 1987) that the floating charge has some restrictions on the company's liberty to manage its assets. For instance, the floating charges usually prohibit the making of other charges ranking prior to or earlier or equal with the floating charge.

Another distinguishing character of a floating charge is contained in section 205 (1) of CAMA which stipulates that when enforced by a court order, a floating chargee may have both receiver and manager appointed, while a fixed chargee can only appoint a receiver In comparing fixed and floating charges, it authoritatively noted that: "A further advantage of a floating charge that a chargee could take power to appoint both receiver and manager over the entire undertaking... instead of merely having to sell specific assets" (Goode, 1988). There is no basis for the proposition that both receiver and manager can only be appointed in respect of a floating charge-for that is the purport of Section 205(1) CAMA. It is difficult to find support for this provision. At common law, both receiver and manager are appointed where the intention is not only to receive and get in assets, but also to carry on the business or undertaking; the conditions for appointment not being dependent on the type of charge, but whether goodwill was expressly or by implication charged (Kerr, 1989). This was also the position until section 205(1) CAMA, having in mind the decision in (Inter Contractors Nigeria Ltd v National Provident Fund Management Board 1988) where Oputa J.S.C. in his concurring judgment held that: when needed for the receiver to do the company's business, the court usually appoints the receiver to be both receiver and manager." Section 205(2) CAMA provides that where a floating charge is yet to be enforced, but the assets charged are in jeopardy-(in terms of it being unreasonable for the company maintaining the freedom to deal in the assets charged) - a receiver or both receiver and manager may be appointed by the court. The grounds for realising charges, and the remedies that follow are now codified by sections 208, 209, 180 (2) and 389 of CAMA in order to make rules on these clear and predictable (Report on the Reform of Nigerian Company Law, vol. 1). The intriguing thing that comes out of these provisions, is that 
the grounds of realization and the remedies available on a floating charge are much wider than those available in a fixed charge.

\subsection{Assets over Which the Floating Charge Can Be Made}

It has been previously mentioned that the floating charge can be extended over all the company's property by virtue of sections 203(1) \& (2) CAMA. Every debenture (trust deed) is required by sections $199 \& 200$ (1) (b) CAMA to make several issues, including the character of the properties charged, in the situation of all charges, and the identity of the specific assets charged in the situation of fixed charges. It follows, that the floating charge not only describes assets charged generally, but goes on to identify them in the body of the charge or by way of a schedule, the charge may be regarded as a fixed charge (Orojo, 1992). The commercial improbability that an enterprise will subject all dealings on all its undertakings and assets to its financier's control (Re Bright life Limited, 1987) may be the justification for section 203 (1) (a) (b) \& (c) of CAMA It is well settled that if it is intended that the chargor should have the freedom to continue dealing in the charged properties the floating charge results, and for this reason, unlike the fixed charge, the floating charge can cover all assets (Lingard, 1993). Put differently, the fixed charge is not permitted to cover all properties

\subsection{Floating Charge Advantages}

The floating charge has various advantages. It is an important means by which the company operates a business. It is used to raise money while the properties of the business are used as security, and also maintaining the company's power to manage its properties of the business. It offers the most convenient way of creating security over the company's assets where there are little or no fixed assets but carries a large and valuable stock in trade (Smith, 2001). The peculiarity of the stock in trade or assets to be turned over in the business has made a fixed charge impracticable, since the approval of the fixed chargee would have to be obtained to sell any asset and a fresh charge has to be entered into when new stocks are acquired. The floating charge enables the stocks to be turned over in the company's business and "attaches to whatever it is adapted into, also to whatever new stock is acquired” (Gower, 1979) without any difficulty. The floating charge affords protection against an unsecured creditor upon crystallization. It gives the floating chargee some degree of control in the company. Such control includes reporting frequently to the chargee and the latter made privy to decisions of management especially in times of financial hardship. The floating charge can also motivate a creditor to give more credit to a business as it develops with expected interests accrued to the creditor. Because a company can manage its charged property in business makes it possible to create a later fixed legal or equitable charge above the floating charge unless the latter provides otherwise (Smith, 2001). 


\section{Legal Importance of Making a Floating Charge}

When created, the floating charge gives an immediate charge over the company's assets but will not attach to the properties until crystlization (Evans v Rival Quarries Ltd., 1910). Thus, while the charge floats, the chargee cannot exercise proprietary or possessory rights over the assets either as against the company or as against third parties, and has no locus stanch to obtain an injunction against the company to restrain it managing its assets in business where the dealings are not in breach of debenture or dependent on the creditor's veto and his security or the guarantee is not in jeopardy (Re Borax Co, 1901). The chargor - company can sell its property and pass a good title to the purchaser (Hammer $v$ London City and Midland Bank, 1918). The purchaser takes the property free from the charge but the money paid becomes dependent on the charge. Where the money is used to acquire an asset, the asset becomes subject to the charge but the purchase money loosed from the charge. The chargor-company may grant a fixed charge over property consisting of a floating charge in the business and a fixed charge. And this will have priority as to the assets on which it is fixed over the floating charge except there is a restriction clause prohibiting the company from creating any fixed charge over property contained inside the floating charge ranking either in preeminence or equal with the floating charge (Re Connally Bros Ltd., 1912). This type of restriction is named Negative Pledge Clause. (NPC)

\section{Negative Pledge Clause (NPC)}

NPC is a crafting formulation introduced in the words used to create the floating charge. This is done to mitigate its vulnerability. It is a special form invented to meet the difficulties that will be encountered in doing the company's business. The clause are covenants that bind the company not to, without the prior agreement of the debenture owner or holder, from granting any subsequent security having preeminence or equal with the existing charge. This covenant when contained in floating charge, limits the scope of the debtor company's dealing power. And by this protect the security while representing equity that binds third parties in common law. The NPC is contained in sections 204 of CAMA. One significant feature of the latter provision is the requirement of definite notice for any later charge for the NPC to be effective. Thus, the NPC contained in a floating charge cannot protect the chargee against a later fixed charge unless the later fixed chargee had definite notice of such prohibition or prevention at the time of creating the charge (2001).

\section{Floating Charge Realization}

In the common law, a creditor is usually given power to select or choose a receiver on the circumstance of default in payment of principal or interest. If this power be absent then the court has an inherent power to appoint one on the occasion of default or even before default when the security is likely to be endan- 
gered (McMahon v North Kent Ironworks Co, 1891). The chargee cannot foreclose, since the charge is an equitable one, the normal remedy is by application for an order of sale by court. The debenture holder may also sue under the personal covenant for payment. Under CAMA, a debenture holder whose debenture is secured by a general floating charge is eligible to realise his security in all the instances that a holder of a fixed security interest may do so. He is also entitled to realise his security on other grounds stipulated in section 232 (2) CAMA. Also, by virtue of section 205 (1) of CAMA, the courts can appoint both receiver and manager. Section 205 (2) also empowers the courts to appoint or choose a receiver where the assets are in jeopardy, or interest or principal is in arrears. Besides court appointed receivership as a method of realizing the floating charge, section 233 (2) of CAMA also provides that both the fixed and floating charges entitles the holder to enforce his security by either appointing a receiver himself, bringing an action in a representative capacity against the company for enforcement and payment of the security, bringing a foreclosure action, or commencing a winding up proceedings.

\section{Vulnerabilities of the Floating Charge}

\subsection{General Vulnerability}

A floating charge holder is not solely concerned with the rights which it provides against the company but equally important, he is concerned with the priority it provides against other charge holders. Regarding the latter aspect the floating charge offers less than perfect security, because of the management autonomy accorded to the company with respect to the charged assets, the company can create security interest that have precedence over the floating charge. The charge holder runs the risk of the company dissipating the assets attached to the charge which arguably is the most serious risk the charge holder faces A floating charge usually will be deferred to any subsequent fixed legal charge created by the company over its assets (Wheatley v Silkshire \& Haigh Moor Coal Co, 1885). Similarly, if the company's debts are under a floating charge, a floating charge holder's asset will be made subject to or put under a lien or any set off created by the company with respect to the charged assets before crystallization. The floating charge for this purpose cannot be regarded as an instant assignment or allotment of the chose in action (Biggerstaff v Rowatt's Wharf, 1896). It becomes such only: on crystallization (Cretanor Maritime Co Ltd v Irish Marine Management Ltd., 1978). If a creditor has imposed or levied and completed execution (Norton v Yates, 1906) the debenture holders cannot force him to return the money, till the charge is crystallized (Evans v Rival Quarries Ltd, 1910). Also, a floating charge holder takes the company's assets subject to the interests of anyone claiming by title paramount. By this, a landlord can re-enter and can distrain on chattels in the leased premises if rent is unpaid, notwithstanding that the chattels are comprised in a charge which has crystallized (Re Roundwood Colliery Co, 1897). In Nigeria, the right to distrain for rent is only available to 
landlord executing a court judgment for arrears of rent. For instance, section. 7 (1) of the Rent Control and Recovery of Residential Premises Edict (No-6 1997 Lagos State).

But if a receiver has been appointed by the court, the court's leave must be obtained, for it is then in possession through its officers (Re Oak Pits Colliery Co, 1887). To keep firm their security against subsequent security by a company which would otherwise have priority, floating charges almost invariably contain a provision-NPC-that restricts the company's right to create charges that have priority to or rank equally with a floating charge. Such restrictions limit the company's actual authority to control its assets and accordingly remove the basis on which floating charges are postponed to later charges. Nevertheless, it has been held by English courts that they may still be postponed to later mortgages, notwithstanding the limitation of the company's authority. If the later mortgage is legal, the mortgagee will obtain priority by virtue of his legal interest unless he has notice not only of the floating charge but also of the restriction in it (English \& Scottish Mercantile Investment Co Ltd v Brunton, 1892). Section 204 of CAMA, stipulates that a fixed chargee must not only be mindful of the existence or reality of a prior floating charge but must also have actual notice of the prohibition contained in the NPC at the time charge was granted to him. Note that even if the charge is registered under sections 222-224 of CAMA, it does not constitute notice of the content of the charge save the particulars in the record of particulars of charges (CAMA section 223 (1)). These particulars set out in sections 222 (9) and 223 (1) of CAMA do not include particulars of prohibitions, conditions or restrictions including any NPC, in the charge. Thus, a later fixed chargee cannot be said to have notice of a NPC contained in an earlier floating charge (Midland Bank Trust Co v Green, 1981). The suggestion that such restriction may be included in the resolution making the charge and be passed by special or extra ordinary resolution which resolution maybe filed pursuant to the provision of section 262 (1) of CAMA. It is to no avail for it does not state notice of the subsequent charge (Smith, 2001). To prove that the fixed chargee had actual notice of the NPC contained in a floating charge created earlier, the floating chargee may show that the holder of the later fixed charge conducted a search of the charge instrument, or that the holder of a future or later fixed charge perused or was given a copy of the charge document to peruse (Smith, 2001).

\subsection{Other Vulnerabilities of a Floating Charge}

There are certain statutory provisions that further add to the vulnerability of a floating charge. These provisions relate to: 1) Preferential creditors which affect the priority of the charge 2) Defective floating charge-which affects the viability of the charge and 3) Cost of the liquidation-which diminishes the available for the floating charge holders.

\subsubsection{Preferential Creditors}

Debenture holders with a floating charge closely resemble shareholders and 
form a class of those assets in the company rather than of those who merely have claims against it. Consequently, it has been thought unjust that they should obtain priority over employees (one of the categories of preferential creditors) who have priority to the shareholders in situation of the company's liquidation. In protecting the interests of these employees or company workers, section 657 (1) of CAMA stipulates that in winding up a company's claim in respect of employees such as wages, salaries, accrued holidays remunerations and social security contributions in the Pensions Reform Act are given preference or priority over claims of other creditors including those of crystallized floating chargee. With respect to this provision, any person who advanced money to pay such wages or salaries is subrogated to the rights of employees so paid (CAMA section 657 (3)). Also, pursuant to modem concept of corporate social responsibility to the public, a duty is by the section imposed on a company to pay, in preference to all other creditors, all rates and taxes due from the company within twelve months (CAMA section 657 (3)). Because the provisions on payment of preferential creditors creates a statutory duty, where a floating chargee or his receiver collects funds out of which preferred debts could have been paid, he will be personally liable to the extent of these funds if the preferred debts are not paid (1RC v Goldblatt, 1972). The statutory duty does not arise however until the preferential claim is proved and becomes payable (1RC v Goldblatt, 1972). It is worthy of note that these statutory limitations does relate to fixed charges, so that fixed charges will not be postponed to claims of preferential creditors (Smith, 2001).

\subsubsection{Defective Floating Charges}

Section 662 of CAMA provides that a floating charge created within 3 months of the beginning of the winding up of the company shall be invalid, unless it is proved that the company immediately after the creation of the charge was solvent. Otherwise, the charge is valid only to the amount of cash paid the company subsequently or at time of making the charge, with interest on that amount at the current bank rate. The effect of this provision is to make it impossible for directors "to retrospectively convert themselves into secured creditors in respect of monies which they have previously advanced without demanding security" (Gower, 1979). It does not also avail directors to advance further money on a floating charge on the understanding that it is to be used to repay their existing loans (Re De Stone Fabrics Ltd., 1914). This restriction on the making of a floating charge close to winding up is inapplicable to fixed charges and a fixed charge is not invalid on the ground that it was granted by an insolvent company immediately before liquidation, although it may be attacked on the ground of fraud or as a fraudulent preference under section 510 of CAMA.

\subsubsection{Cost of Liquidation}

Both under common law and sections 647 and 648 of CAMA, expenses of the company's liquidation are payable out of the properties of the company in pre- 
ference to other claims. In (Re Barley Corn Enterprises Ltd., 1970) the English court held that assets charge constituted properties of the company paying the costs of liquidation. Vulnerability of a floating charge could also be seen from the defect of allowing too much initiative to the chargor. Also, when crystallization occurs, the fortunes of the chargor may have sunk so low that a chargee has virtually lost the "collateral".

\section{Conclusion}

The paper examined the character and efficacy of a floating charge in Nigerian law. It argued that though the floating charge has advantage, its disadvantages are so much making it a vulnerable security. The vulnerability includes: the charge holder runs the risk of the company dissipating the assets attached to the charge which arguably is the most serious risk the charge holder faces. Furthermore, a floating charge usually will be deferred to any subsequent fixed legal charge created by the company over its assets. Similarly, if the company's debts are under a floating charge, a floating charge holder's asset will be made subject to or put under a lien or any set off created by the company with respect to the charged assets before crystallization Also, a floating charge holder takes the company's assets subject to the interests of anyone claiming by title paramount. Also, there are some provisions in the Nigerian Companies and Allied Matters Act that further add to the vulnerability of a floating charge. These provisions relate to: preferential creditors (which affect the priority of the charge), defective floating charge (which affects the viability of the charge), cost of liquidation (which diminishes the available funds for the floating charge holders). Given the vulnerability of a floating charge, one question arises as to why a creditor should bother to obtain one. While obviously the fixed charge accords superior protection, there are a few reasons for taking a floating charge. Firstly, the charge provides security against unsecured creditors. Secondly, the chargee will be able to take steps to enforce the charge and this accords him considerable control over the company's affairs. Thirdly, before crystallization the chargor company has authority to manage its properties in business. In all, the vulnerability of a floating charge makes it not to be a perfect security and as such not necessary in current business transactions. Even if the chargee institutes the NPC in a floating charge, that will not protect the chargee against a later fixed charge unless the lath fixed chargee had actual notice of such prohibition at the time of making the charge. The fixed charge is better and therefore recommended. As stated earlier a fixed charge fastens at once on the charged property, and binds it in hands of third parties who take from the company. From the point of view of the chargee, the advantage of the fixed charge lies in the availability of particular assets to satisfy the creditor upon default by the debtor company. And also, in ranking of the charge over any floating charge made prior to or subsequent to a fixed charge. The significance of this research is to bring to the fore the vulnerabilities of a floating charge as a security so that a potential investor can seek other more 
secured securities.

\section{Conflicts of Interest}

The author declares no conflicts of interest regarding the publication of this paper.

\section{References}

1RC v Goldblatt (1972). Ch 458.

Animashnun v Olojo (1990). 16 NWLR (Pt. 154) 111.

Armagh Shoes Limited (1984). BCLC 405.

Australian Auxiliary Steam Clip per Co. v. Mounsey (1958). 4 KB 733.

Biggerstaff v Rowatt's Wharf (1896). 2 Ch 93, CA.

Blacks (1990). Law Dictionary (6th ed.). Saint Paul, MN: West Publishing Co.

Bryan v Metropolitan Co (1858). 3 De G \& J 123.

Companies and Allied Matters Act, 2020.

Cretanor Maritime Co Ltd v Irish Marine Management Ltd (1978). 1 WLR 966 CA.

English \& Scottish Mercantile Investment Co Ltd v Brunton (1892). 2 QB 700 CA.

Evans v Rival Quarries Ltd (1910). 2 KB 979.

Goode, R. (2008). Goode on Legal Problems of Credit and Security (4th ed.). London: Sweet and Maxwell.

Goode, R. M. (1988). Legal Problems of Credit and Security (2nd ed.). London: Sweet \& Maxwell.

Gower, L. C. B. (1979). Principles of Modern Company Law (4th ed.). London: Sweet and Maxwell.

Hammer v London City and Midland Bank (1918). 87 LJ.K.8. 973.

Holroyd v Marshal (1862). LR 10 I-TLC 191.

Illingsworth v Houldsworth (1904). AC 355.

Inter-Contractors Nigeria Ltd v. National Provident Fund Management Board (1988). 2 NWLR (Pt.76) 280.

Kerr, W. W. (1989). Receivers and Administrators (17th ed., pp. 214-216). London: Sweet \& Maxwell.

Knightsbridge Estates Trust Ltd v Byrne (1940). AC 613.

Lingard, J. R. (1993). Bank Security Documents (3rd ed.). London: Butterworths.

McCormack, G. (2009). Registration of Company Charges (3rd ed.). Jordan Publishing.

McMahon v North Kent Ironworks Co (1891). 2 Ch 148.

Midland Bank Trust Co v Green (1981). All ER 153 at 158-159.

Norton v Yates (1906). 1 KB 112 CA.

Ogundiani v Araba (1978). 11 NSCC 334.

Orojo, O. (1992). Company Law \& Practice in Nigeria (3rd ed.). Mbeyi \& Associates (Nig) Ltd.

Palmer, F. G., \& Schmitthoff, C. M. (1976). Palmer's Company Law (22nd ed.). Stevens \& Sons.

Pennington, R. (1960). The Genesis of the Floating Charge. The Modern Law Review, 23, 
630-646. https://doi.org/10.1111/j.1468-2230.1960.tb00630.x

Pennington, R. (1995). Company Law (7th ed.). London: Butterworths.

Re Barley Corn Enterprises Ltd (1970). Ch 465.

Re Borax Co (1901). 1 Ch. 326.

Re Bright life Limited (1987). 1 Ch 200.

Re Cimex Tissues Limited (1995). 1 BCLC.

Re Connally Bros Ltd (1912). 2 Ch. 25.

Re Crompton \& Co. Ltd (1914). 1 Ch. 964.

Re De Stone Fabrics Ltd (1914). 319 CA.

Re G E Turnbridge Ltd (1994). BCC 563.

Re New Bullas Trading Ltd (1994). 1 BCLC 485.

Re Oak Pits Colliery Co (1887). 21 Ch D 322 CA.

Re Panama, New Zealand and Australian Royal Mail Co. (1870). 5 Ch.App. 318.

Re Pyle Works (1990). 44 Ch 534.

Re Roundwood Colliery Co (1897). 1 Ch 373 CA.

Re Yorkshire Wool Combers Association Limited (1903). 2 Ch 284 per Romer LJ.

Report on the Reform of Nigerian Company Law, vol. 1, 148.

Santley v. Wilde (1899). Cli. 474.

Siebe German \& Co. Ltd v Barclays Bank Ltd (1979). 2 Lloyd's Rep. 12.

Smith, I. O. (2001). Nigerian Law of Secured Credit. London: Ecowatch Publications Limited.

Tailby v Qfficial Receiver (1888). 13 App Cas 523.

Wheatley v Silkshire \& Haigh Moor Coal Co (1885). 29 Ch D 715. 